\title{
Mating sequence, dominance and paternity success in captive male tammar wallabies
}

\author{
Emily F Hynes ${ }^{1}$, Carl D Rudd ${ }^{2}$, Peter D Temple-Smith ${ }^{1}$, George Sofronidis ${ }^{1}$, Damien Paris ${ }^{1}$, \\ Geoff Shaw ${ }^{1}$ and Marilyn B Renfree ${ }^{1}$ \\ ${ }^{1}$ Department of Zoology, University of Melbourne, Victoria 3010, Australia and ' 'Goonderoo', MS472275, \\ Queensland, Springsure, 4722, Australia
}

Correspondence should be addressed to M B Renfree; Email: m.renfree@zoology.unimelb.edu.au

\begin{abstract}
The tammar wallaby (Macropus eugenii) is a small, promiscuous, macropodid marsupial. Females usually produce a single young each year and there is a clear dominance hierarchy between adult males. The dominant male usually mates first and then guards the female to prevent access to her by other males. In this study, agonistic encounters and mating behaviour were observed to determine male dominance hierarchies in six groups of captive tammars consisting of a total of 23 males and 50 females. Mating behaviour was observed immediately post-partum when females were in oestrus and was correlated with plasma testosterone concentrations. Male mating sequences were recorded, and the paternity of offspring was determined by using seven macropodid marsupial microsatellites. Rates of sexual checking and aggression by males housed with females in oestrus in the non-breeding season were lower than in the breeding season. These males also had lower concentrations of testosterone, but were still able to sire young. High testosterone concentrations neither ensured dominance nor appeared to control directly the level of sexual activity. Females usually mated with more than one male. The dominant male most often secured the initial copulation $(60 \%)$, but the first-mating male did not always secure parentage, with second and third matings resulting in as many young as first matings. Using these data, we were unable to discount first sire, last sire or equal chance models of paternity in this species. Half the young $(50 \%)$ were sired by the dominant $\alpha$ male, but of the remaining progeny, the $\beta$ male sired more (35\%) than $\gamma$ and $\delta$ males $(15 \%)$. Dominance therefore is only a moderately effective predictor of paternity in the tammar. Although the dominant males gained most first matings and individually sired half of the offspring, the subdominant males still contributed significantly to the population, at least in captivity.

Reproduction (2005) 130 123-130
\end{abstract}

\section{Introduction}

The tammar wallaby is a highly synchronous, seasonally breeding, macropodid marsupial with a multimale mating system (Flint \& Renfree 1982, Tyndale-Biscoe \& Renfree 1987). During the breeding season in late January or early February, $83 \%$ of females give birth and enter oestrus (Renfree \& Tyndale-Biscoe 1973). The tammar has a postpartum oestrus and normally mates about $1 \mathrm{~h}$ after birth (Rudd 1994). Ovulation occurs about $40 \mathrm{~h}$ later (Renfree \& Lewis 1996) and the resulting conceptus develops to the blastocyst stage and enters an 11-month period of embryonic diapause while the young is reared in the pouch (Tyndale-Biscoe \& Renfree 1987). Seventeen per cent of females are non-parous (Renfree \& Tyndale-Biscoe 1973). These females will cycle, enter oestrus and mate in January, and then give birth and undergo post-partum oestrus in February. Between February and June, any female that loses her young will reactivate the diapausing blastocyst, and after a pregnancy of about 1 month will give birth and enter oestrus again.

In contrast to seasonally breeding eutherians such as the sheep, which shows seasonal regression of the testes (Legan et al. 1977, Lincoln \& Davidson 1977), the male tammar wallaby produces spermatozoa throughout the year (Inns 1982). In the wild, male tammar wallabies show a rise in serum testosterone in late January coinciding with the onset of the breeding season, but testosterone concentrations are low for most of the year (Catling \& Sutherland 1980, Inns 1982). There is a second small increase in late October when juvenile females leave their mother's pouches and enter their first oestrus. The weight of the prostate and Cowper's glands fluctuate seasonally in response to testosterone (Inns 1982, Williams et al. 1998). In the major breeding season (January/February), the male reproductive tract is heaviest, 
ejaculation volume and coagulation index are the greatest, and sperm motility is highest (Paris 2004).

Access to tammar females by males is essential for the seasonal increase in testosterone concentrations. Males that are isolated from females in the breeding season do not show a rise in plasma testosterone (Catling \& Sutherland 1980). Olfactory stimuli are clearly important in signaling the reproductive condition of females, and males monitor the reproductive status of females by sniffing their urogenital region or pouch (sexual checking) (Renfree et al. 1989, Rudd 1994). Castrated males show a substantial decrease in male-typical sexual behaviour, such as sexual checking and copulatory behaviour, while females implanted with testosterone have the same level of sexual behaviour as intact males (Rudd et al. 1996). These testosterone-implanted females all showed increased aggression toward copulating males, suggesting that malelike levels of testosterone can activate copulation-induced aggression (Rudd et al. 1996).

In species where females mate with multiple males, reproductive success results from both precopulatory and postcopulatory strategies (Ginsberg \& Huck 1989, Preston et al. 2003). Sperm competition occurs when an oestrous female mates with more than one male in a single reproductive cycle (Ginsberg \& Huck 1989, Møller \& Birkhead 1989, Parker 1990). Male tammar wallabies attempt to reduce the chance of sperm competition by various mechanisms, including extensive pre- and postcopulatory mate guarding behaviour with frequent mating (Ewen et al. 1993, Rudd 1994, Rudd et al. 1996), relatively large ejaculate volumes and epididymal sperm stores, large testicular size and ejaculated sperm concentrations, and production of large, firm copulatory plugs (Tyndale-Biscoe \& Renfree 1987, Paris 2004, Paris et al. 2004). These plugs may enhance reproductive success by increasing sperm retention in the female tract, by locating spermatozoa in close apposition to the cervix and improving sperm transport into the cervix and uterus, and/or by acting as temporary barriers (chastity enhancement) to sperm deposition by other males (Murie \& McLean 1980, Michener 1984, Toner et al. 1987, Cukierski et al. 1991a, 1991b, Taggart \& Shimmin 1999, Jia et al. 2002), although evidence in some species does not support chastity enhancement (Koprowski 1992, Moreira \& Birkhead 2004). Success of these measures usually depend on a large ratio of testis to body weight, which in the tammar is around $0.5 \%$ (unpublished data of R V Short in Tyndale-Biscoe \& Renfree 1987, Rose 1997, Taggart et al. 1998), and is similar to that found in 31 multimating mammals (Kenagy \& Trombulak 1986).

The $\alpha$ male tammar wallaby usually controls initial access to oestrous females by mating first and guarding the female against advances by subordinate males for up to $8 \mathrm{~h}$ (Rudd 1994), although mate guarding by the $\alpha$ male prevents ejaculations by subordinates in only half the matings (Rudd 1994). In a group of four captive tammar males allowed to mate with 13 females, there was no significant difference in the number of young sired by each male (Ewen et al. 1993). However, no behavioural observations were made in that study to verify social structure or record mating sequences.

Recent genetic analyses show that paternity cannot accurately be inferred from male dominance hierarchies or even from observed matings. In some cases, dominance or copulation frequency reliably reflects parentage (Cowlishaw \& Dunbar 1991, Altmann et al. 1996, Roed et al. 2002), but in others there is minimal correlation (Coltman et al. 1999, Soltis et al. 2001). A dominant male can achieve a higher proportion of paternity in two main ways: by decreasing the ability of subordinates to mate with and fertilize females, such as by suppression of gonadotrophin or testosterone, as occurs in subordinate males of lesser mouse lemurs (Perret 1992) and marsupial sugar gliders (Stoddart et al. 1994, Bradley \& Stoddart 1997), and by the superior ability of dominant males to compete for and guard oestrous females against matings by subordinate males.

The aim of this study was to examine further the paternity success of males in several groups of captive tammar wallabies in both the major breeding season and in the non-breeding season by recording the mating sequence and paternity success of each male in relation to its dominance rank and its sexual and aggressive behaviour.

\section{Materials and Methods}

\section{Animals}

Tammar wallabies of Kangaroo Island (South Australia) origin were housed in grassy paddocks in our breeding colony in Victoria, Australia. The grass was supplemented with oats, lucerne cubes, fresh vegetables and water ad libitum. Care and treatment of animals conformed to the National Health and Medical Research Council of Australia guidelines (1997), and all experimental work was approved by Animal Experimentation Ethics Committees at Monash University and the University of Melbourne.

\section{Blood sampling}

Blood was drawn from the lateral tail vein into a $5 \mathrm{ml}$ syringe coated with either sodium heparin $(50 \mu \mathrm{l}$ of $125 \mathrm{IU} / \mathrm{ml}$ ) (CSL, Parkville, Australia), for testosterone assay, or EDTA $(1.5 \mathrm{~g} / \mathrm{ml}$ blood) (Sigma), for DNA extraction, and stored at $-20^{\circ} \mathrm{C}$ in plastic $5 \mathrm{ml}$ tubes (Sarstadt, Australia, Pty Ltd) until assayed. When required for DNA extraction, the buffy coat was aspirated and stored at $-20^{\circ} \mathrm{C}$.

Blood was taken from adult males in the colony every 1-4 weeks from February 2002 until February 2003 to determine the annual cycle of change in testosterone concentrations. These males were housed with seven females with both male and female pouch young that were born in March 2002. A total of 17 males (different from those used for the behavioural study) were sampled over the year, with 4-6 of these males sampled in each month. Blood was assayed for testosterone. 


\section{Testosterone radioimmunoassay}

Plasma testosterone concentrations were measured by a radioimmunoassay validated for the tammar (Williamson et al. 1990). The antiserum (no. 457) (Bioquest Ltd, Artarmon, NSW, Australia) has a cross-reactivity of $100 \%$ with testosterone, $98 \%$ with $5 \alpha$-dihydrotestosterone, $47 \%$ with 4 -androsten- $3 \beta, 17 \beta$-diol, $4.7 \%$ with androstendione and $3.6 \%$ with 4 -androsten-17 3,19 -diol-3-one. The sensitivity of the assay was $10 \mathrm{pg} /$ tube. Double extractions gave an efficiency of $87 \pm 4.5 \%$. Plasma $(0.2 \mathrm{ml})$ was extracted twice with hexane:toluene (2:1) (Merck), freshly mixed before each assay. The extract was redissolved in $0.7 \mathrm{ml}$ assay buffer, and duplicate $0.3 \mathrm{ml}$ aliquots were assayed. Testosterone added to blank plasma was recovered quantitatively ( $y=0.9558 x-6.4192, r=0.9994, P=0.0017)$. Plasma pools with high and low testosterone concentration were included in each assay as quality controls. The intra-assay coefficient of variation was $9.2 \%(n=10)$. The interassay coefficient of variation was $14.6 \%(n=5)$.

\section{Behavioural observations}

A total of five groups were observed during the breeding season. In January/February 2003, two groups were observed (group 1: 3 males, 15 females; group 2: 4 males, 13 females). In March 1995, three groups were observed (group 4: 4 males, 9 females; group 5: 4 males, 8 females; group 6: 4 males, 5 females). A single further group was observed in September/October 2003 during the nonbreeding season (group 3: 4 males, 13 females).

Pregnancies were initiated between late January and mid-April in both 1995 and 2003 by removal of pouch young (RPY) from lactating females. This reactivates the diapausing blastocyst (Tyndale-Biscoe \& Renfree 1987), birth occurs 26.5 days later (Renfree et al. 1989) and females enter a post-partum oestrus within $1 \mathrm{~h}$ of birth (Rudd 1994). Blood samples were collected each week from males in groups 1 and 2 at the peak of the breeding season between 20 January and 11 February 2003, and assayed for testosterone.

Out-of-season births and matings were induced in September in the 13 group 3 females, housed with 4 males, by $50 \mathrm{mg}$ melatonin implanted under the pouch skin to terminate seasonal quiescence (Renfree \& Short 1984, McConnell et al. 1986). Blood samples were taken from the males from the day the implants were inserted (day 0) and then on days 6, 13, 20, 27, 31, 41 and 71, and assayed for testosterone. Blood samples were also collected daily from 14-18 October in the non-breeding season from group 3 males and assayed for testosterone.

Wallabies were identified by colour-coded collars and tape on the tail. During observation periods, animals were kept in yards either $12 \times 15$ or $25 \times 15 \mathrm{~m}$. Floodlights were used for night viewing. Observations were made with the assistance of $7 \times 35$ binoculars from an observation platform $2 \mathrm{~m}$ above ground level. Every $5 \mathrm{~min}$, the enclosure was scanned visually to locate all animals and note their current behaviour. Any female showing signs of parturition (Renfree et al. 1989) was monitored until mating was complete ('complete mating sequence'). The time and duration of copulations and mounts were recorded. During undisturbed mating, there is an initial period of about 30-60 s of mounting, intromission and pelvic thrusting, followed by about 6-8 min in copula without thrusting (Rudd 1994). Ejaculation presumably occurs at the time when thrusting ceases, as uncoagulated semen is often observed exuding from the urogenital region of the female soon after completion of thrusting. A copulating male was considered to have ejaculated when he stopped thrusting. Behavioural observations were made from dusk to dawn, and some further observation periods were made during the day, opportunistically, if any reproductive behaviour was noted.

Dominance hierarchies were determined by noting behaviour during male-male interactions over resources such as food, shelter, space and females. Interactions were either scored as a win, a loss or a draw. A win was defined as an occasion where one male displaces another, while a loss was when a male was displaced. A draw required both males retreating equal distances from each other, or neither retreating. A dominance score was calculated for each male by the method designed by Jameson et al. (1999). This method is based on a mathematical model of paired comparisons and takes into account the percentage of wins as well as the competitive ability of opponents. A dominance hierarchy for each group was determined on the basis of these scores.

A scoring system was used to analyse sexual activity. Sexual checking was defined as the male sniffing and/or nosing the pouch or cloacal area of the female (1 point). After checking a female, the male often cuffed the female, or pawed her tail or back (2 points). The female frequently moved away in response to this behaviour. If the male followed, 3 points were allocated and 4 points for blocking the female's path. A copulation attempt was allocated 5 points.

\section{Paternity analysis}

Seven microsatellite markers developed for the tammar by Taylor and Cooper (1998) were used to assign parentage to offspring. Microsatellite PCR primers were modified with Oligo 4.0 for Macintosh. DNA was extracted from blood of adults and the tails of pouch young. Most extractions were carried out by the standard salting-out procedure (Miller et al. 1998). The remaining DNA was extracted with the DNeasy Tissue Kit (Qiagen) and methods outlined in the DNeasy Tissue Handbook (May 2002). Blood and buffy coat samples (100 $\mu \mathrm{l})$ were processed according to the isolation of DNA from whole non-nucleated blood' protocol and pouch young tails $(6 \mathrm{~mm})$ were extracted according to the 'DNeasy protocol for rodent tails'. These were both modified by performing two $100 \mu$ l elutions of EA buffer instead of one $200 \mu \mathrm{l}$ elution, to improve the DNA yield. The concentration of DNA in extracts was determined by loading 1 and $2 \mu \mathrm{l}$ 
aliquots of sample into a $0.8 \%$ agarose gel (Scientifix, Cheltenham, Australia) stained with ethidium bromide (Sigma). Samples were run on a gel at $110 \mathrm{~V}$ for $30 \mathrm{~min}$. DNA concentration was estimated visually by comparing density of bands of unknown DNA with samples of known concentrations $(25 \mathrm{mg} / 10 \mu \mathrm{l}, 50 \mathrm{mg} / 10 \mu \mathrm{l}, 75 \mathrm{mg} / 10 \mu \mathrm{l}$ and $100 \mathrm{mg} / 10 \mu \mathrm{l})$. DNA from 2002/2003 experiments was then diluted to approximately $2.5 \mathrm{ng} / \mathrm{ml}$ and delivered to the Australian Genome Research Facility for PCR and microsatellite analysis.

The conditions for microsatellite analysis were optimized, as described in Taylor and Cooper (1998). Paternity was assigned by exclusion principles because allele frequencies for the population were not available. Of the two known alleles, one was assumed to be inherited from the mother and the other from the father. Males that had an allele that did not match that of the young were excluded. A male with matching alleles for known microsatellites was assumed to be the father, provided that all remaining group males had been excluded.

Microsatellite primers were [gamma ${ }^{33} \mathrm{P}$ ] incorporated (Amersham Pharmacia Biotech, Castle Hill, NSW, Australia) with $\mathrm{T}$ kinase (New England Biolabs, Beverly, MA, USA) before amplification. PCR reactions of $10 \mu \mathrm{l}$ contained 100-120 ng DNA, $2.5 \mathrm{mM} \mathrm{MgCl} 2,1 \times$ reaction buffer (Life Technologies Invitrogen, Mt Waverley, Victoria, Australia), $20 \mathrm{mM}$ Tris $-\mathrm{HCl}(\mathrm{pH} 8.4), 50 \mathrm{mM} \mathrm{KCl}, 0.5 \mathrm{U}$ Taq polymerase (Life Technologies), $200 \mu \mathrm{M}$ of dNTPs, $0.3 \mu \mathrm{M}$ radioactively labeled reverse primer and $0.2 \mu \mathrm{M}$ forward primer with mineral oil overlay. PCR amplifications were carried out in a Corbett Thermocycler (Corbett Research Australia, Mortlake, NSW) and consisted of an initial denaturation at $94^{\circ} \mathrm{C}$ for $5 \mathrm{~min}$ and then 30 cycles of $30 \mathrm{~s}$ at $94^{\circ} \mathrm{C}, 30 \mathrm{~s}$ at Ta optimised for each primer $47-$ $54^{\circ} \mathrm{C}$ ) and $1 \mathrm{~min}$ at $72^{\circ} \mathrm{C}$. The final elongation step was $72{ }^{\circ} \mathrm{C}$ for $10 \mathrm{~min}$. PCR products were run on $6 \%$ denaturing polyacrylamide gels and visualized by autoradiography. Size of fragments was determined by comparison with a standard sequencing reaction of pUC18 DNA (Promega).

\section{Statistical analysis}

Changes in testosterone concentration were analysed by either one-way ANOVA or Student's t-test (Prism, Graphpad, Graphpad Software Pty Ltd, San Diego, CA, USA). Correlations between testosterone and sexual behaviour were tested by Spearman correlations (Prism, Graphpad). Student's $t$-test was used to compare rates of agonistic encounters in the breeding season and the non-breeding season.

The observed mating and paternity successes for the complete mating sequences were compared by log likelihood analysis with three different sperm competition models: first mating paternity success, last mating paternity success and equal chance of success for all males that successfully mated with a female.

\section{Results}

Males housed with females in the colony had a clear annual cycle in plasma testosterone concentrations, reaching a peak of $9.68 \pm 1.26 \mathrm{ng} / \mathrm{ml}$ in late January (Fig. 1). Concentrations were relatively low during the period of shortest days in May and June $(0.38 \pm 0.08 \mathrm{ng} / \mathrm{ml})$. Plasma testosterone increased in January, coinciding with the beginning of the breeding season (ANOVA: $P=0.0002$ ) Testosterone decreased during February, as the number of females in oestrus diminished. Testosterone concentrations increased again toward the end of February as those females that mated but did not give birth in January entered oestrus post-partum.

Plasma testosterone concentrations increased slightly from $0.56 \pm 0.19$ (7 Oct.) to $1.44 \pm 0.53 \mathrm{ng} / \mathrm{ml}$ (18 Oct) in three out of four males housed with melatoninimplanted group 3 females at about the time the females were in midpregnancy after reactivation, and fell gradually to basal levels by November. The peak testosterone concentrations in these males $(2.7 \pm 2.6 \mathrm{ng} / \mathrm{ml})$ were well below the $10-15 \mathrm{ng} / \mathrm{ml}$ recorded in all males in the breeding season groups (Fig. 1). This difference was highly significant ( $t$-test: $P=0.0001$ ).

Males in the non-breeding season group were involved in fewer agonistic interactions than males in the breeding season groups $(0.79 \pm 0.21$ vs $0.28 \pm 0.08$ interactions $/ \mathrm{h}$, $P=0.03)$. Dominance rank was significantly correlated with body weight $(P<0.01)$ : the heaviest males had the highest rank and the lightest males the lowest $(\alpha$ males averaged $7.5 \pm 0.2 \mathrm{~kg} ; \beta, 7.1 \pm 0.3 \mathrm{~kg} ; \gamma, 6.3 \pm 0.1 \mathrm{~kg} ; \delta$, $6.1 \pm 0.4 \mathrm{~kg}$ ). Plasma testosterone concentration was not clearly correlated with dominance rank in either breeding or non-breeding season (Fig. 2).

The average rates of sexual behaviour and checking were significantly higher in the breeding season than in the nonbreeding season (ANOVA $P=0.008$ ). Rates of checking

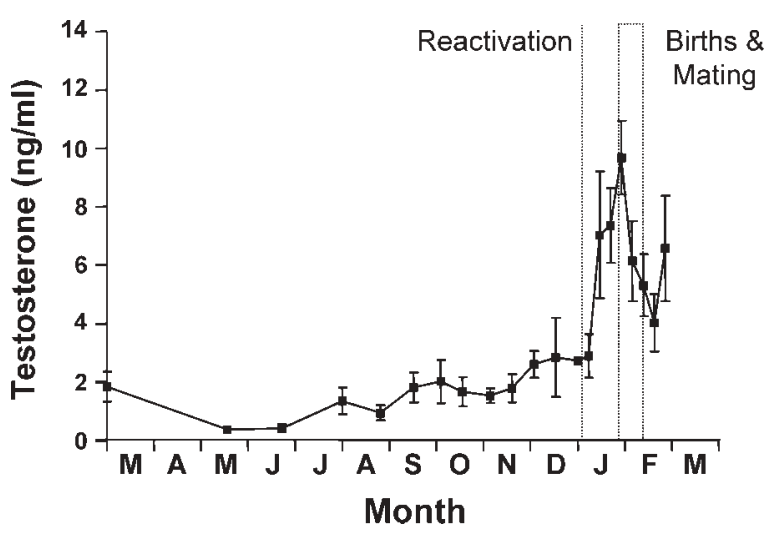

Figure 1 Plasma testosterone concentration (ng/ml, mean \pm S.E.M., $n=4-7$ in each month) in males bled $1-3$ times/month between February 2002 and February 2003. Testosterone concentrations rose significantly in colony males soon after reactivation of the blastocysts, reaching highest concentrations from late January to early February when females give birth and enter post-partum oestrus. 


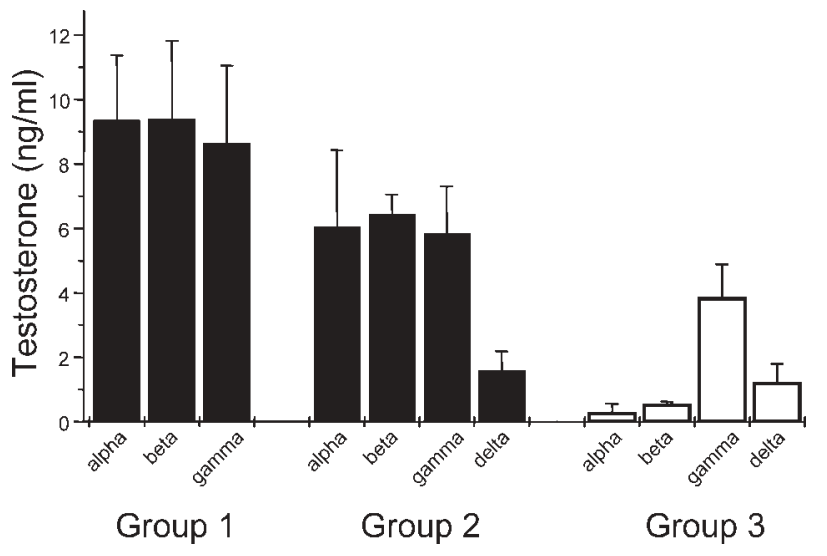

Figure 2 Plasma testosterone ( $\mathrm{ng} / \mathrm{ml} \pm$ S.E.M.) of males in Groups $1 \& 2$ in the breeding season (Jan-Feb; solid bars) and one Group 3 (open bars) in the non-breeding season (Oct.). Testosterone concentrations are significantly higher in the breeding season, but there is no clear correlation between dominance rank at either time of the year.

for individual males were correlated with both peak testosterone (Spearman correlation: $r=0.671, P=0.028$ ) and average testosterone (Spearman correlation $r=0.679$, $P=0.025$ ) over the observation period. However, the total amount of sexual activity (as determined by sexual score per day) did not correlate with peak (Spearman correlation; $r=0.465, P=0.15$ ) or average testosterone (Spearman correlation; $r=0.340, P=0.30)$.

Matings were observed for 40 females (Figs 3 and 4), but in only 24 of these was it possible to conduct observations for long enough to be certain that all matings to the last had been recorded ('complete mating sequences'). In this group, there were 7 single matings, 8 double matings, 5 females mated with 3 different males, and 4 females mated with 4 different males. From the 40 observed matings, the dominant male secured the first copulation on $60.0 \%$ of occasions. All single, male postpartum matings $(n=7)$ were by $\alpha$ males. However, $\alpha$ males were unable to monopolise initial copulations, and the lower ranking males ejaculated first in some cases ( $\beta$ males: 8/40 (20\%), $\gamma$ males: 4/40 (10\%), $\delta$ males: 4/40 (10\%) (Fig. 3a). Timed observations of the behaviour of males from group 2 in relation to four different females and one female from group 4 confirmed that the first mating did not always result in successful fertilization, nor did the $\alpha$ male always sire the pouch young (Fig. 4).

Of 36 pouch young born during this study, it was possible to confirm paternity by genotyping for 20 young, while for the remaining 16, genotyping did not result in unambiguous assignment of paternity. Of the 20 where paternity was assigned, $\alpha$ males sired 10 young (50\%) (Fig. 3b) $\beta$ males sired $7(35 \%)$ and $\gamma$ males sired 3 pouch young $(15 \%)$ respectively (Table 1 ). No $\delta$ males secured paternity. We obtained data on paternity for only $9 / 24$ females for which we had complete mating sequences. Of these, the male that mated first secured parentage in 4 sequences (44.4\%), but in
A

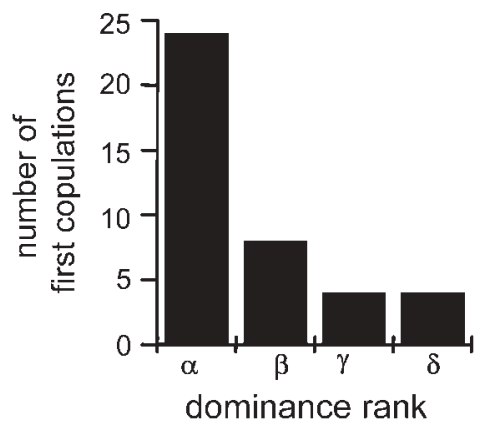

B

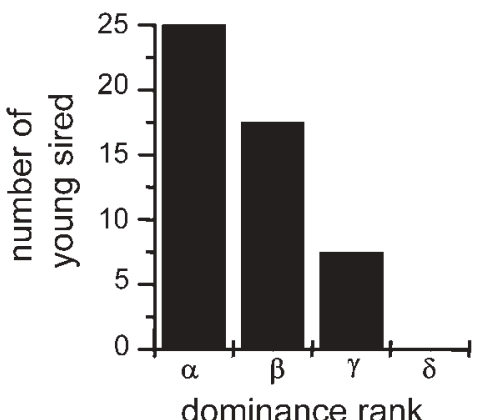

c

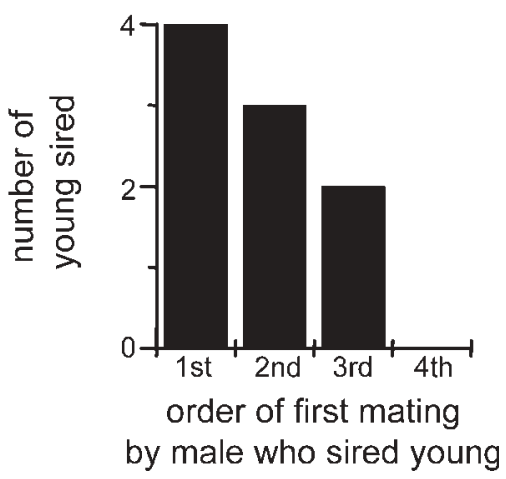

Figure 3 (A) Number of copulations by males of different ranks. The higher ranked males achieved a greater number of first copulations. (B) Number of young sired by males of different ranks. The higher ranked males achieved a greater number of copulations. (C) Number of young sired in relation to first copulation by the father. More young resulted from early than later copulations.

$3(33.3 \%)$ and $2(22.2 \%)$ sequences respectively the second and third copulations achieved paternity (Fig. 3c).

Using the mating sequences of the 24 females for which the full mating sequence was observed, we generated predictions of paternity based on three models. In the 'first sire' or 'last sire' models, the first or last mating male was predicted to be the sire respectively, and in the 'equal chance' model, any male that mated with the female was considered to have the same chance of siring the young as any other male in that mating sequence. These predictions were compared by a log linear model, with the observed frequency of siring by dominance ranking in the 20 animals for which paternity was determined (Fig. 3b). None of the three models were significantly different from 

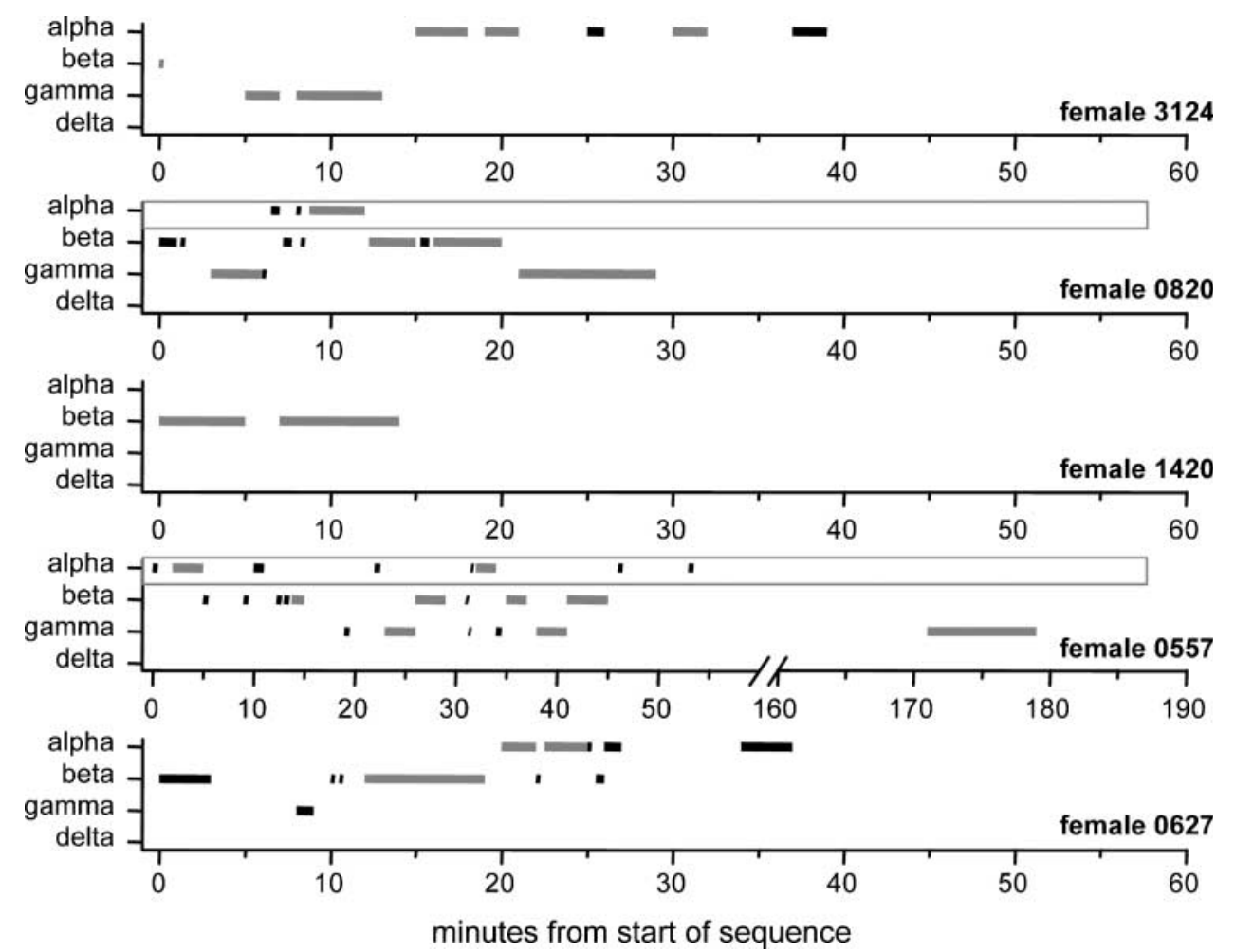

Figure 4 Examples of mating and mounting sequences of females, showing duration of mounts and matings. Paternity is known for females 0557 and 0820. In both, the $\alpha$ male is the father and was the first and second copulating male respectively. In one example (top), the $\gamma$ male secured the first mating. Grey bars, copulation; black bars, mounting; boxes assign Paternity.

the observed ( $P>0.1$ in all comparisons) (Table 1). None of these models could therefore discounted in this study.

\section{Discussion}

Male tammar wallabies show a marked increase in testosterone in January at the peak of the breeding and birth season. In these males and those housed with the melatonin-implanted females, this rise in testosterone coincided with the middle of active gestation, suggesting that the increase may result from pheromones induced by the rise in progesterone (or other pregnancy hormones) at this time. This rise in testosterone has been assumed to be important in establishing sexual behaviour, but the role of testosterone in establishing dominance hierarchies is less clear because the dominant male does not necessarily

Table 1 Observed and predicted paternity success based on mating first, last or in any sequence.

\begin{tabular}{lcrcc}
\hline & & \multicolumn{3}{c}{ Prediction from model } \\
\cline { 3 - 5 } Sire & Observed & First $^{1}$ & Last $^{2}$ & Equal chance $^{3}$ \\
\hline$\alpha$ & 10 & 16 & 10 & 12.7 \\
$\beta$ & 7 & 4 & 6 & 5.3 \\
$\gamma$ & 3 & 2 & 4 & 3.2 \\
$\delta$ & 0 & 2 & 4 & 2.8 \\
\hline
\end{tabular}

${ }^{1} P=0.112 ;{ }^{2} P=0.219 ;{ }^{3} P=0.269$.

Reproduction (2005) $130123-130$ have higher circulating testosterone concentrations than subordinates in his hierarchy. Although rates of sexual checking and aggression were lower in the non-breeding season when testosterone concentrations are lower, in the breeding season when testosterone concentration was significantly elevated, it did not necessarily increase the level of sexual activity or ensure dominance. In contrast, the heaviest (largest) males showed dominance over all other males in the group. Dominance confers some advantages for paternity success, and the $\alpha$ male was able to secure the initial copulation most frequently. However, mating first does not appear to be the only mechanism by which the dominant male achieved the greatest paternity. Other physiological or behavioural attributes of dominant males may be of equal or greater importance for successful paternity in the tammar. Dominant males may have larger epididymal sperm reserves and may, therefore, be able to ejaculate greater numbers of spermatozoa during copulation than subordinate males, or be able to produce a larger number of effective ejaculates, or to displace semen of subordinate males that mate before them. They may also, by their behavioural dominance, be able to reduce the copulatory success of subordinate males by mate guarding and fighting, as observed by Rudd (1994).

The lack of relationship in the tammar between dominance rank and testosterone indicates that the testosterone (and thus fertilizing ability) of subordinates is not 
suppressed by rank. In another marsupial, the sugar glider, the dominant male has a significantly higher testosterone concentration than subordinates. The potential advantages of this testosterone-linked dominance in sugar gliders is reflected in the higher paternity achieved by the $\alpha$ male (over $75 \%$ of conceptions annually) (Mallick et al. 1994, Stoddart et al. 1994) and assisted by the smaller numbers of males $(2-3)$ in male dominance hierarchies of this species.

Dominance in the tammar appears to be a function of body size and aggression and is usually associated with a greater competitive ability. Testosterone has been linked with aggression in many species, including the tammar, and acts of aggression in this study were more prevalent in the breeding season when testosterone concentrations were greater (Rudd et al. 1996). Dominance is a moderate predictor of paternity success in the captive tammar wallaby, yet paternity success does not always result from mating first. This is surprising, as the tammar has some characteristics often associated with a first-mating advantage, including mate guarding and the formation of a copulatory plug (Rudd 1994). Dominance correlates positively with larger size in male tammars and many other species of macropodids (Kaufmann 1974, Croft 1981, Rudd 1994, Fisher 1999). In the tammar, larger size is associated with heavier reproductive organs (Inns 1982, Paris 2004), suggesting that the dominant male has a greater fertilizing capability via greater ejaculate volume, higher coagulation index of ejaculates and higher proportion of motile sperm (Paris 2004). Thus, a contributing mechanism by which $\alpha$ males secure paternity may be by enhanced sperm competition.

In the first study of paternity in tammars, no male sired significantly more young than any other in a small group of 4 males and 13 females that produced 22 young (progeny sired per male were 8, 6, 4 and 4) (Ewen et al. 1993). This may have been influenced by the synchronous oestrus of the females, since one male cannot guard two or more females simultaneously, but the two largest males sired the most young. In a group of captive male red-necked wallabies (Macropus rufogriseus), at least $20 \%$ of young were not fathered by the dominant male, showing that the dominant male was unable to monopolise paternity (Watson et al. 1992). In that study, exact parentage was not able to be determined; thus, the number not sired by the dominant male is likely to have been much higher.

In most observed mating sequences from our study, the $\alpha$ male was unable to prevent other males from mating with the female. This is not purely an artefact of captivity, as tammars in the wild on Kangaroo Island in January mate with up to 5-7 males in a single oestrus (M B Renfree \& G Shaw; unpublished observations). The inability of the dominant male to guard mates successfully and prevent copulation by subordinates is well documented for the tammar (Rudd 1994). The guarding activity of male tammars tends to be thwarted by the female's engaging in behaviour, such as mating chases, that draws the attention of other males to her oestrous state (Rudd 1994). Caviomorph rodents have similar behaviour (Sachser et al. 1999). This advertisement of oestrus through conspicuous activity, such as calling and chasing, induces male-male competition so that females can mate with the most competitive male (Cox \& Le Boueff 1977). Current theory suggests that the selective pressures from this male-male conflict have led to the evolution of the sexual size dimorphism seen in many species, including the tammar (Harcourt et al. 1981, Rudd 1994).

In the male tammar wallaby, there is intense competition for oestrous females. Females mate with more than one male; and the $\alpha$ male secures more than half, but not all, initial copulations. However, since dominant males mate first on only $60 \%$ of occasions, and only $50 \%$ of the young are sired by the dominant male, neither the mating sequence nor dominance is a reliable predictor of paternity success in the tammar.

\section{Acknowledgements}

We thank the staff at the Australian Genome Research Facility (Parkville, Melbourne) for assistance with the microsatellite genotyping. We also thank Sue Osborn, Scott Brownlees, Kerry Martin and members of the wallaby research group for assistance with the animals. The authors declare that there is no conflict of interest that would prejudice the impartiality of this scientific work.

\section{References}

Altmann J, Alberts SC, Haines SA, Dubach J, Muruthi P, Coote T, Geffen E, Cheesman DJ, Mututua RS, Saiyalel SN, Wayne RK, Lacy RC \& Bruford MW 1996 Behavior predicts genetic structure in a wild primate group. PNAS 93 5797-5801.

Bradley AJ \& Stoddart DM 1997 Plasma androgen, social position, and response to GnRH in the marsupial sugar glider Petaurus breviceps (Marsupialia: Petauridae). Journal of Zoology 241 579-587.

Catling PC \& Sutherland RL 1980 Effect of gonadectomy, season and the presence of female tammar wallabies (Macropus eugenii) on concentrations of testosterone, luteinizing hormone and follicle-stimulating hormone in the plasma of male tammar wallabies. Journal of Endocrinology 86 25-33.

Coltman DW, Bancroft DR, Robertson A, Smith JA, Clutton-Brock TH \& Pemberton JM 1999 Male reproductive success in a promiscuous mammal: behavioural estimates compared with genetic paternity. Molecular Ecology 8 1199-1209.

Cowlishaw G \& Dunbar RIM 1991 Dominance rank and mating success in male primates. Animal Behaviour 41 1045-1056.

Cox C \& Le Boueff B 1977 Female incitation of male competition: a mechanism in sexual selection. American Naturalist 111 317-335.

Croft DB 1981 Social behaviour of the euro, Macropus robustus (Gould), in the Australian arid zone. Australian Wildlife Research 8 13-49.

Cukierski MA, Sina JL, Prahalada S \& Robertson RT 1991a Effects of seminal vesicle and coagulating gland ablation on fertility in rats. Reproductive Toxicology 5 347-352.

Cukierski MA, Sina JL, Prahalada S, Wise LD, Antonello JM, MacDonald JS \& Robertson RT 1991b Decreased fertility in male rats administered the 5-alpha reductase inhibitor finasteride is due to deficits in copulatory plug formation. Reproductive Toxicology $\mathbf{5}$ 353-362.

Ewen KR, Temple-Smith PD, Bowden DK, Marinopoulos J, Renfree MB \& Yan H 1993 DNA fingerprinting in relation to male dominance and paternity in a captive colony of tammar wallabies 
(Macropus eugenii). Journal of Reproduction and Fertility 99 33-37.

Fisher DO 1999 Effects of body size and home range on access to mates and paternity in male bridled nailtail wallabies. Animal Behaviour 58 121-130.

Flint APE \& Renfree MB 1982 Oestradiol-17 $\beta$ in the circulation during seasonal reactivation of the diapausing blastocyst in a wild population of tammar wallabies, Macropus eugenii. Journal of Endocrinology 95 293-300.

Ginsberg JR \& Huck UW 1989 Sperm competition in mammals. Trends in Ecology and Evolution 4 74-79.

Harcourt A, Harvey P, Larson S \& Short R 1981 Testis weight, body weight and breeding system in primates. Nature 293 55-57.

Inns RW 1982 Seasonal changes in the accessory reproductive systems and plasma testosterone levels of the male tammar wallaby, Macropus eugenii, in the wild. Journal of Reproduction and Fertility $\mathbf{6 6} 675-680$.

Jameson KA, Appleby MC \& Freeman LC 1999 Finding an appropriate order for a hierarchy based on probabilistic dominance. Animal Behaviour 57 991-998.

Jia Z, Duan E, Jiang Z \& Wang D 2002 Copulatory plugs in masked civets: prevention of semen leakage, sperm storage, or chastity enhancement? Journal of Mammalogy 83 1035-1038.

Kaufmann JH 1974 Social ethology of the whiptail wallaby, Macropus parryi, in northeastern NSW. Animal Behaviour 22 281-369.

Kenagy GJ \& Trombulak SC 1986 Size and function of mammalian testes in relation to body size. Journal of Mammalogy 67 1-22.

Koprowski JL 1992 Removal of copulatory plugs by female tree squirrels. Journal of Mammalogy 73 572-576.

Legan SJ, Karsch FJ \& Foster DL 1977 The endocrine control of seasonal reproductive function in the ewe: a marked change in response to the negative feedback action of estradiol on luteinizing hormone secretion. Endocrinology 101 818-824.

Lincoln GA \& Davidson W 1977 The relationship between sexual and aggressive behaviour, and pituitary and testicular activity during the seasonal sexual cycle of rams, and the influence of photoperiod. Journal of Reproduction and Fertility 49 267-276.

Mallick J, Stoddart DM, Jones I \& Bradley AJ 1994 Behavioral and endocrinological correlates of social status in the male sugar glider (Petaurus breviceps Marsupialia: Petauridae). Physiology and Behavior $551131-1134$.

McConnell SJ, Tyndale-Biscoe CH \& Hinds LA 1986 Change in duration of elevated concentrations of melatonin is a major factor in photoperiod response of the tammar, Macropus eugenii. Journal of Reproduction and Fertility 77 623-632.

Michener GR 1984 Copulatory plugs in Richardson's ground squirrels Spermophilus richardsonii. Canadian Journal of Zoology 62 267-270.

Miller SA, Dykes DD \& Plesky HF 1988 A simple salting out procedure for extracting DNA from human nucleated cells. Nucleic Acids Research 161215 .

Møller AP \& Birkhead TR 1989 Copulation behavior in mammals: evidence that sperm competition is widespread. Biological Journal of the Linnean Society 38 119-132.

Moreira PL \& Birkhead TR 2004 Copulatory plug displacement and prolonged copulation in the Iberian rock lizard (Lacerta monticola). Behavioural Ecology and Sociobiology 56 290-297.

Murie JO \& McLean I 1980 Copulatory plugs in ground squirrels. Journal of Mammalogy 61 355-356.

Paris DBBP 2004 Semen quality and fertilization in natural and artificial inseminations in the tammar wallaby, Macropus eugenii. PhD thesis, University of Melbourne.

Paris DBBP, Taggart DA, Paris M, Temple-Smith P \& Renfree MB 2004 Sperm transport, the size of the seminal plug and the timing of ovulation after natural mating in the female tammar wallaby, Macropus eugenii. Reproduction, Fertility and Development 16 811-822.

Paris DBBP, Taggart DA, Paris M, Temple-Smith P \& Renfree MB 2005 Birth of the pouch young after artificial insemination in the tammar wallaby, Macropus eugenii. Biology of Reproduction 72 451-459.
Parker GA 1990 Sperm competition games - raffles and roles. Proceedings of the Royal Society, London B 242 120-126.

Perret M 1992 Environmental and social determinants of sexual function in the male lesser mouse lemur (Microcebus murinus). Folia Primatologia 59 1-25.

Renfree MB \& Tyndale-Biscoe CH 1973 Intra-uterine development after diapause in the marsupial Macropus eugenii. Developmental Biology 32 28-40.

Renfree MB \& Short RV 1984 Seasonal reproduction in marsupials. In 7th International Congress of Endocrinology, pp 789-792. Eds F Labrie \& L Proulx. Amsterdam: Elsevier.

Renfree MB \& Lewis AM 1996 Cleavage in vivo and in vitro in the marsupial Macropus eugenii. Reproduction, Fertility and Development 8 725-742.

Renfree MB, Fletcher TP, Blanden DR, Lewis PR, Shaw G, Gordon K, Short RV, Parer-Cook E \& Parer D 1989 Physiological and behavioural events around the time of birth in macropodid marsupials. In Kangaroos, Wallabies and Rat-Kangaroos, pp 323-337. Eds G Grigg, P Jarman \& I Hume. Sydney: Surrey Beatty.

Roed KH, Holand O, Smith ME, Gjostein H \& Kumpula J 2002 Reproductive success in reindeer males in a herd with varying sex ratio. Molecular Ecology 111239.

Rose RW 1997 Testes weight, body weight and mating systems in marsupials and monotremes. Journal of Zoology 243 523-531.

Rudd CD 1994 Sexual behaviour of the male and female tammar wallabies (Macropus eugenii) at postpartum oestrus. Journal of Zoology 232 151-162.

Rudd CD, Short RV, Shaw G \& Renfree MB 1996 Testosterone control of male-type sexual behavior in the tammar wallaby (Macropus eugenii). Hormones and Behavior 30 446-454.

Sachser N, Schwarz-Weig E, Keil A \& Epplen JT 1999 Behavioural strategies, testis size, and reproductive success in two caviomorph rodents with different mating systems. Behaviour 136 1203-1217.

Soltis J, Thomsen R \& Takenaka O 2001 The interaction of male and female reproductive strategies and paternity in wild Japanese macaques, Macaca fuscata. Animal Behaviour 62 485-494.

Stoddart DM, Bradley AJ \& Mallick J 1994 Plasma testosterone concentration, body weight, social dominance and scent-marking in male marsupial sugar gliders (Petaurus breviceps; Marsupialia: Petauridae). Journal of Zoology 232 595-601.

Taggart DA \& Shimmin GA 1999 Sperm competition: a marsupial perspective. Victorian Naturalist 116 58-64.

Taggart DA, Breed WG, Temple-Smith PD, Purvis A \& Shimmin GA 1998 Reproduction, mating strategies and sperm competition in marsupials and monotremes. In Sperm Competition and Sexual Selection, pp 623-666. Eds TR Birkhead \& AP Møller. London: Academic Press.

Taylor AC \& Cooper DW 1998 A set of tammar wallaby (Macropus eugenii) microsatellites tested for genetic linkage. Molecular Ecology 7 925-931.

Toner JP, Attas Al \& Adler NT 1987 Transcervical sperm transport in the rat: the roles of pre-ejaculatory behavior and copulatory plug fit. Physiology and Behavior 39 371-376.

Tyndale-Biscoe CH \& Renfree 1987 In Reproductive Physiology of Marsupials. Cambridge: Cambridge University Press.

Watson DM, Croft DB \& Crozier RH 1992 Paternity exclusion and dominance in captive red-necked wallabies, Macropus rufogriseus, Marsupialia, Macropodidae. Australian Mammology 15 31-36.

Williams SC, Fletcher TP \& Renfree MB 1998 Puberty in the female tammar wallaby. Biology of Reproduction 58 1117-1122.

Williamson P, Fletcher TP \& Renfree MB 1990 Testicular development and the maturation of the hypothalmic-pituitary-testicular axis in the male tammar, Macropus eugenii. Journal of Reproduction and Fertility $\mathbf{8 8} 549-557$.

Received 16 December 2004

First decision 11 February 2005 